84

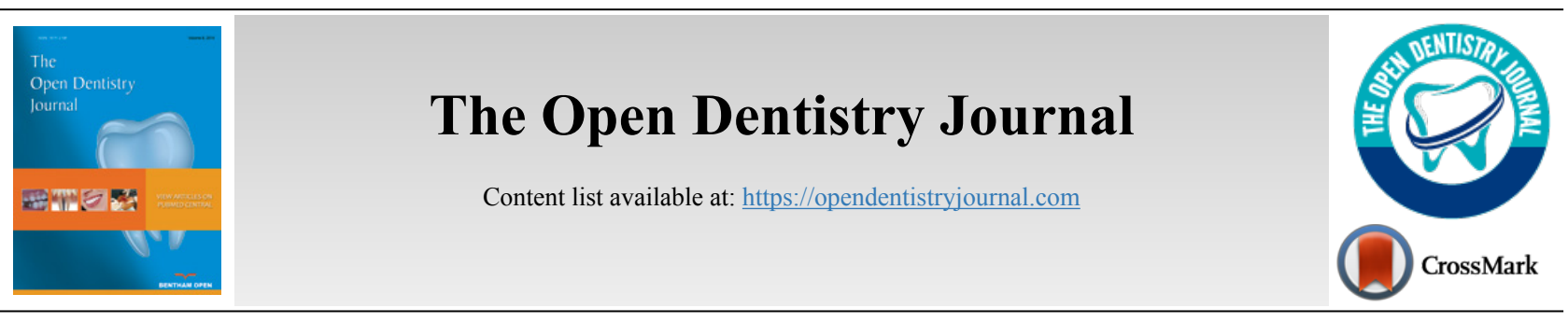

RESEARCH ARTICLE

\title{
New Advances On Biomaterials for Regenerative and Reparative Treatment Following Periodontal and Peri-implant Diseases
}

Gaetano Isola ${ }^{1, *}$

${ }^{\prime}$ Department of General Surgery and Surgical-Medical Specialties, Unit of Oral Pathology, School of Dentistry, University of Catania, Catania, Italy

Recent data show that the correct management of periodontitis and peri-implantitis represents a potential challenge in the health system $[1,2]$. Periodontal disease and peri-implantitis are multifactorial diseases with infectious aetiology which, following an important immune response of the host [3, 4], culminating in the progressive loss of supporting tissues, alveolar bone and finally determine the loss of the tooth or of the implant [5] and that affect patients' quality of life [6 - 8]. However, in addition to these conditions, the morphostructural alteration of the stomatognathic system's hard and soft tissues can be determined by teeth extraction, trauma, prosthetic restorations [9] oral tumors, and pathological conditions such as severe dental or skeletal malocclusions [10, $11]$.

A correct relationship between neoformation and bone resorption is fundamental in order to maintain, in the long term, the periodontal [12] and peri-implant support tissues. It has been widely demonstrated that homeostasis and tropism of periodontal and peri-implant tissues are regulated by specific cellular pathways, with highly advanced intra- and intercellular regulation and signaling mechanisms [13 - 16].

However, in the last few decades, research in digital dentistry [17 - 19], oral tissues and regenerative engineering has made great strides in successfully managing the problems arising from these pathologies, and having as its primary objective that of regenerating missing or damaged tissues in order to obtain a correct restoration of the periodontal and periimplant apparatus.

In recent years, more and more efforts in the clinical and scientific fields have been made in the field of periodontal tissue engineering and with the aim of obtaining the regeneration of periodontal hard and soft tissues through specific customized approaches with the use of growth factors,

* Address correspondence to this author at the Department of General Surgery and Surgical-Medical Specialties, School of Dentistry, University of Catania, Via S.Sofia 78, Catania, 95123 Italy; Tel/Fax: +390953782453;

E-mail: gaetano.isola@unict.it scaffolds and highly innovative materials [20] that allow to regenerate the missing tissue and, at the same time, to guarantee excellent aesthetics and function [21].

The research in the engineering field of the oromaxillofacial district has been directed in order to guarantee an increasingly specific and personalized approach that also assesses the different clinical condition [22], specific and environmental site of the patient affected by periodontal disease [23 - 25].

In this regard, the developed dental engineering was aimed at finding a wide range of techniques focused on the management and regulation of the many molecular pathways at the genetic level that is activated during inflammatory and infectious pathologies of the craniofacial district [26].

Periodontal and bone regeneration is essentially applied for the treatment of peri-implant periodontal hard tissue dehiscences, as well as in some conditions related to alveolar ridge defects that require augmentation for subsequent oral rehabilitation $[27,28]$. In dentistry, some challenges in the regeneration of periodontal tissue and augmentation of alveolar bone include the development of strategies to optimize regeneration according to specific masticatory forces at the interface between the avascular surface of the tooth and implant, associated with microbial contamination of the gingival biofilm $[29,30]$. To address the complexity of oral regeneration and rehabilitation, several approaches of a multidisciplinary nature have been developed that span both clinical and basic research.

For these reasons, a correct approach from molecular to clinical manufacturing and nanotechnology must therefore be assessed in a holistic and multidisciplinary way in order to be able to develop a successful therapeutic strategy to treat patients with diseased periodontal and peri-implant tissues [31, 32].

Therefore, a correct knowledge of the microbial biofilm and host defense mechanisms, in physiological and 
pathological conditions is a fundamental approach for the patients [33, 34]. In fact, in most cases of treatment of periodontal or peri-implant disease, a simple disintegration of the bacterial biofilm through a surgical or non-surgical approach does not allow to fix tissue integrum.

Therefore, there is a need to establish specific treatment plans that evaluate the best strategies that allow obtaining real healing of periodontal or peri-implant defects and improve the long-term prognosis of the patients with periodontitis and periimplantitis.

Recently, efforts have been made in recent years to predictably stimulate true bone regeneration of periodontal tissues by introducing bioactive models or constructing patientspecific bone substitutes or growth factors [5, 35].

In this regard, this special issue was aimed to analyze and update the current knowledge on the most recent therapies and approaches of orofacial disorders [36, 37].

More specifically, in this special issue, several highly current problems have been addressed, including the treatment alternative for Obstructive Sleep Apnea Syndrome (OSAS), the modern approaches to structural alterations such as Stafne's bone cavity, the telemedicine approach for orofacial pain, maxillary expansion and, above all, the remote treatment and monitoring of the patient suffering from oral diseases during COVID-19 infection. There have been many key advances in the field of periodontal engineering and regeneration in various pathological conditions over the past few decades. In the future, bioengineering applied to pathologies of the facial area will allow obtaining a better therapeutic response through the development and use of specific biomimetic scaffolds highly performing to the needs of the individual patient. However, despite these recent and exciting developments, much work remains to be done to translate these interesting preliminary results into traditional routine clinical practice. Furthermore, future research should better match and validate approaches based on tissue biology and engineering, in order to obtain products that always give more predictable and reproducible results on a large scale and allowing obtaining the maximum function, aesthetics and best quality of care of the single patient through increasingly personalized approaches.

Therefore, in the next few years, all that remains is to instill significant scientific and clinical efforts in order to improve research in the engineering and regenerative fields to better treat and with a personalized approach the pathologies of the oral and maxillofacial district.

\section{REFERENCES}

[1] Van Dyke TE. Shifting the paradigm from inhibitors of inflammation to resolvers of inflammation in periodontitis. J Periodontol 2020; 91(Suppl. 1): S19-25. [http://dx.doi.org/10.1002/JPER.20-0088] [PMID: 32441774]

[2] Righolt AJ, Jevdjevic M, Marcenes W, Listl S. Global-, Regional-, and Country-Level Economic Impacts of Dental Diseases in 2015. J Dent Res 2018; 97(5): 501-7. [http://dx.doi.org/10.1177/0022034517750572] [PMID: 29342371]

[3] Isola G, Polizzi A, Patini R, Ferlito S, Alibrandi A, Palazzo G. Association among serum and salivary A. actinomycetemcomitans specific immunoglobulin antibodies and periodontitis. BMC Oral Health 2020; 20(1): 283.

[http://dx.doi.org/10.1186/s12903-020-01258-5] [PMID: 33059645]
[4] Isola G, Polizzi A, Alibrandi A, Williams RC, Leonardi R. Independent impact of periodontitis and cardiovascular disease on elevated soluble urokinase-type plasminogen activator receptor (suPAR) levels. J Periodontol 2020.

[http://dx.doi.org/10.1002/JPER.20-0242] [PMID: 33091149]

[5] Rakic M, Monje A, Radovanovic S, Petkovic-Curcin A, Vojvodic D, Tatic Z. Is the personalized approach the key to improve clinical diagnosis of peri-implant conditions? The role of bone markers. J Periodontol 2020; 91(7): 859-69.

[http://dx.doi.org/10.1002/JPER.19-0283] [PMID: 31773730]

[6] Polizzi A, Santonocito S, Di Stefano M, Ferlito S, Indelicato F, Palazzo G. The effects on Oral Related Quality of Life induced by periodontitis in patients with juvenile idiopathic arthritis. Mediterr J Clin Psyc 2020; 8(1)

[7] Polizzi A, Santonocito S, Vaccaro M, et al. Relationship between periodontitis and psychosocial impact in patients with systemic sclerosis: A clinical study. Mediterr J Clin Psyc 2020; 8(2)

[8] Santonocito S, Ronsivalle V, Fichera G, Indelicato F. Psychological impact and patient perception of occlusion and orthodontic treatment in periodontitis patients. Mediterr J Clin Psyc 2020; 8(9)

[9] Lo Giudice A, Ortensi L, Farronato M, Lucchese A, Lo Castro E, Isola G. The step further smile virtual planning: milled versus prototyped mock-ups for the evaluation of the designed smile characteristics. BMC Oral Health 2020; 20(1): 165.

[http://dx.doi.org/10.1186/s12903-020-01145-z] [PMID: 32503567]

[10] Lo Giudice A, Leonardi R, Ronsivalle V, et al. Evaluation of pulp cavity/chamber changes after tooth-borne and bone-borne rapid maxillary expansions: a CBCT study using surface-based superimposition and deviation analysis. Clin Oral Investig 2020. [http://dx.doi.org/10.1007/s00784-020-03539-3] [PMID: 32860529]

[11] Fichera G, Polizzi A, Scapellato S, Palazzo G, Indelicato F. Craniomandibular disorders in pregnant women: An epidemiological survey. J Funct Morphol Kinesiol 2020; 5(2)E36

[http://dx.doi.org/10.3390/jfmk5020036] [PMID: 33467252]

[12] Leonardi R, Loreto C, Talic N, Caltabiano R, Musumeci G. Immunolocalization of lubricin in the rat periodontal ligament during experimental tooth movement. Acta Histochem 2012; 114(7): 700-4. [http://dx.doi.org/10.1016/j.acthis.2011.12.005] [PMID: 22209395]

[13] Musumeci G, Trovato FM, Loreto C, et al. Lubricin expression in human osteoarthritic knee meniscus and synovial fluid: a morphological, immunohistochemical and biochemical study. Acta Histochem 2014; 116(5): 965-72.

[http://dx.doi.org/10.1016/j.acthis.2014.03.011] [PMID: 24932985]

[14] Musumeci G, Castrogiovanni P, Mazzone V, Szychlinska MA, Castorina S, Loreto C. Histochemistry as a unique approach for investigating normal and osteoarthritic cartilage. Eur J Histochem 2014; 58(2): 2371 .

[http://dx.doi.org/10.4081/ejh.2014.2371] [PMID: 24998926]

[15] Loreto C, Leonardi R, Musumeci G, Pannone G, Castorina S. An ex vivo study on immunohistochemical localization of MMP-7 and MMP-9 in temporomandibular joint discs with internal derangement. Eur J Histochem 2013; 57(2)e12

[http://dx.doi.org/10.4081/ejh.2013.e12] [PMID: 23807291]

[16] Musumeci G, Carnazza ML, Leonardi R, Loreto C. Expression of $\beta$ defensin-4 in "an in vivo and ex vivo model" of human osteoarthritic knee meniscus. Knee Surg Sports Traumatol Arthrosc 2012; 20(2): 216-22.

[http://dx.doi.org/10.1007/s00167-011-1630-x] [PMID: 21879330]

[17] Lo Giudice A, Ronsivalle V, Lagravere M, Leonardi R, Martina S, Isola G. Transverse dentoalveolar response of mandibular arch after rapid maxillary expansion (RME) with tooth-borne and bone-borne appliances. Angle Orthod 2020; 90(5): 680-7.

[http://dx.doi.org/10.2319/042520-353.1] [PMID: 33378488]

[18] Leonardi R, Farella M, Cobourne MT. An association between sella turcica bridging and dental transposition. Eur J Orthod 2011; 33(4): 461-5.

[http://dx.doi.org/10.1093/ejo/cjq106] [PMID: 21212168]

[19] Leonardi R, Annunziata A, Caltabiano M. Landmark identification error in posteroanterior cephalometric radiography. A systematic review. Angle Orthod 2008; 78(4): 761-5.

[http://dx.doi.org/10.2319/0003-3219(2008)078[0761:LIEIPC]2.0.CO; 2] [PMID: 18302479]

[20] Leonardi R, Almeida LE, Trevilatto PC, Loreto C. Occurrence and regional distribution of TRAIL and DR5 on temporomandibular joint discs: comparison of disc derangement with and without reduction. Oral Surg Oral Med Oral Pathol Oral Radiol Endod 2010; 109(2): 244-51. 
[http://dx.doi.org/10.1016/j.tripleo.2009.09.028] [PMID: 20123409]

[21] Abate A, Cavagnetto D, Fama A, Matarese M, Bellincioni F, Assandri F. Efficacy of Operculectomy in the Treatment of 145 Cases with Unerupted Second Molars: A Retrospective Case-Control Study In: Dent J (Basel) . 2020; 8.(3)

[22] Mercuri E, Cassetta M, Cavallini C, Vicari D, Leonardi R, Barbato E. Dental anomalies and clinical features in patients with maxillary canine impaction. Angle Orthod 2013; 83(1): 22-8.

[http://dx.doi.org/10.2319/021712-149.1] [PMID: 22639824]

[23] Lee JH, Park YS, Kim YT, Kim DH, Jeong SN. Assessment of early discomfort and wound healing outcomes after periodontal surgery with and without enamel matrix derivative: an observational retrospective case-control study. Clin Oral Investig 2020; 24(1): 229-37. [http://dx.doi.org/10.1007/s00784-019-02941-w] [PMID: 31079246]

[24] Zhu C, Zhao Y, Wu X, et al. The therapeutic role of baicalein in combating experimental periodontitis with diabetes via $\mathrm{Nrf} 2$ antioxidant signaling pathway. J Periodontal Res 2020; 55(3): 381-91. [http://dx.doi.org/10.1111/jre.12722] [PMID: 31854466]

[25] Taskan MM, Balci Yuce H, Karatas O, Gevrek F, Toker H. Evaluation of the effect of oleuropein on alveolar bone loss, inflammation, and apoptosis in experimental periodontitis. J Periodontal Res 2019; 54(6): 624-32.

[http://dx.doi.org/10.1111/jre.12662] [PMID: 31032945]

[26] Musumeci G, Carnazza ML, Loreto C, Leonardi R, Loreto C. $\beta$ Defensin-4 (HBD-4) is expressed in chondrocytes derived from normal and osteoarthritic cartilage encapsulated in PEGDA scaffold. Acta Histochem 2012; 114(8): 805-12.

[http://dx.doi.org/10.1016/j.acthis.2012.02.001] [PMID: 22564496]

[27] Portelli M, Gatto E, Matarese G, et al. Unilateral condylar hyperplasia: diagnosis, clinical aspects and operative treatment. A case report. Eur J Paediatr Dent 2015; 16(2): 99-102.

[PMID: 26147813]

[28] Cordasco G, Nucera R, Fastuca R, et al. Effects of orthopedic maxillary expansion on nasal cavity size in growing subjects: a low dose computer tomography clinical trial. Int $\mathrm{J}$ Pediatr Otorhinolaryngol 2012; 76(11): 1547-51.

[http://dx.doi.org/10.1016/j.ijporl.2012.07.008] [PMID: 22840779]

[29] Cosgarea R, Tristiu R, Dumitru RB, et al. Effects of non-surgical periodontal therapy on periodontal laboratory and clinical data as well as on disease activity in patients with rheumatoid arthritis. Clin Oral
Investig 2019; 23(1): 141-51

[http://dx.doi.org/10.1007/s00784-018-2420-3] [PMID: 29589156]

[30] Iorio-Siciliano V, Blasi A, Stratul SI, et al. Anti-infective therapy of peri-implant mucositis with adjunctive delivery of a sodium hypochlorite gel: a 6-month randomized triple-blind controlled clinical trial. Clin Oral Investig 2019.

[http://dx.doi.org/10.1007/s00784-019-03060-2] [PMID: 31432311]

[31] Yan K, Lin Q, Tang K, et al. Substance P participates in periodontitis by upregulating HIF- $1 \alpha$ and RANKL/OPG ratio. BMC Oral Health 2020; 20(1): 27.

[http://dx.doi.org/10.1186/s12903-020-1017-9] [PMID: 32000757]

[32] Kang W, Liang Q, Du L, Shang L, Wang T, Ge S. Sequential application of bFGF and BMP-2 facilitates osteogenic differentiation of human periodontal ligament stem cells. J Periodontal Res 2019; 54(4): 424-34.

[http://dx.doi.org/10.1111/jre.12644] [PMID: 30851068]

[33] Blufstein A, Behm C, Gahn J, et al. Synergistic effects triggered by simultaneous Toll-like receptor-2 and -3 activation in human periodontal ligament stem cells. J Periodontol 2019; 90(10): 1190-201. [http://dx.doi.org/10.1002/JPER.19-0005] [PMID: 31049957]

[34] Sulijaya B, Takahashi N, Yamazaki K. Host modulation therapy using anti-inflammatory and antioxidant agents in periodontitis: A review to a clinical translation. Arch Oral Biol 2019; 105: 72-80.

[http://dx.doi.org/10.1016/j.archoralbio.2019.07.002]

[PMID: 31288144]

[35] Fang D, Yuran S, Reches M, Catunda R, Levin L, Febbraio M. A peptide coating preventing the attachment of Porphyromonas gingivalis on the surfaces of dental implants. J Periodontal Res 2020; 55(4): 503-10.

[http://dx.doi.org/10.1111/jre.12737] [PMID: 32096230]

[36] Grassia V, D'Apuzzo F, Ferrulli VE, Matarese G, Femiano F, Perillo

L. Dento-skeletal effects of mixed palatal expansion evaluated by postero-anterior cephalometric analysis. Eur J Paediatr Dent 2014; 15(1): 59-62.

[PMID: 24745595]

[37] Dekel E, Nucci L, Weill T, et al. Impaction of maxillary canines and its effect on the position of adjacent teeth and canine development: A cone-beam computed tomography study. Am J Orthod Dentofacial Orthop 2021; 159(2): e135-47.

[http://dx.doi.org/10.1016/j.ajodo.2020.10.015] [PMID: 33388201]

(C) 2021 Gaetano Isola

This is an open access article distributed under the terms of the Creative Commons Attribution 4.0 International Public License (CC-BY 4.0), a copy of which is available at: https://creativecommons.org/licenses/by/4.0/legalcode. This license permits unrestricted use, distribution, and reproduction in any medium, provided the original author and source are credited. 